\title{
1 A pilot-scale coupling catalytic ozonation-membrane filtration system for recirculating aquaculture wastewater treatment
}

5 1. Key Laboratory of Industrial Ecology and Environmental Engineering (Ministry of

6 Education, China), School of Environmental Science and Technology, Dalian

7 University of Technology, Dalian 116024, China.

8 2. School of Fisheries and Life Science, Dalian Ocean University, Dalian 116023, 9 China.

11 Corresponding author's name: Xie Quan

12 Mail address: School of Environmental Science and Technology, Dalian University of

13 Technology, Dalian, China, 116024.

14 Tel: +86-411-84706140; Fax: +86-411-84706263; E-mail: quanxie@dlut.edu.cn 
1 A pilot-scale coupling catalytic ozonation-membrane filtration system for recirculating aquaculture wastewater treatment

\author{
Shuo Chen ${ }^{1}$, Jinqi $\mathrm{Yu}^{1}$, Hua Wang ${ }^{1,2}$, Hongtao $\mathrm{Yu}^{1}$, Xie Quan ${ }^{1 *}$
}

4 1. Key Laboratory of Industrial Ecology and Environmental Engineering (Ministry of

5 Education, China), School of Environmental Science and Technology, Dalian

6 University of Technology, Dalian 116024, China.

7 2. School of Fisheries and Life Science, Dalian Ocean University, Dalian 116023 ,

8 China.

9 Abstract

10 A pilot-scale coupling catalytic ozonation-membrane filtration system was designed

11 for the recirculating aquaculture wastewater treatment at a fish farm. The ceramic

12 membranes were coated with $\mathrm{Ti}-\mathrm{Mn} / \mathrm{TiO}_{2}$ oxide for both catalytic ozonation and

13 filtration. Scanning electron microscopy (SEM) and energy dispersive X-ray

14 spectroscopy (EDX) images showed that the Ti-Mn oxides were distributed smoothly

15 over both the membrane surface and the inner walls of the pores. Compared with the

$16 \mathrm{TiO}_{2} / \mathrm{Al}_{2} \mathrm{O}_{3}$ membranes, the $\mathrm{Ti}-\mathrm{Mn} / \mathrm{TiO}_{2} / \mathrm{Al}_{2} \mathrm{O}_{3}$ membranes exhibited better catalytic

17 ozonation capability with enhanced membrane antifouling (a normalized permeate

18 flux obtained after $2 \mathrm{~h}$ operation was 0.56 ) and higher removal efficiency of organic

19 matters $(52.1 \%)$. The ozone dose has an important effect on the degradation of

20 organic matters and ammonia. At an ozone dose of $52 \mathrm{mg} / \mathrm{min}$ (stable permeate was 
1 obtained after $1 \mathrm{~h}$ operation), turbidity and nitrite were almost completely removed,

2 and the concentration of total ammonia nitrogen (TAN) dropped to less than $0.1 \mathrm{mg} / \mathrm{L}$.

3 The permeate quality satisfied the water quality requirement for aquaculture. The

4 recovery ratio of the aquaculture seawater was as high as $95.8 \%$.

5 Keywords: pilot-scale, catalytic ozonation, membrane filtration, ceramic membranes,

6 aquaculture water treatment

\section{1. Introduction}

8 The limited suitable water supplies, the absence of land sources and concerns over

9 the environmental pollution are regarded as key obstacles to further expansion of

10 traditional flow-through aquaculture systems [1]. Thus, recirculating aquaculture

11 systems, which can remove solids, organic matters and total ammonia nitrogen, and

12 can kill microbes to realize low water exchange compared with flow-through systems,

13 are of great interest in aquaculture water treatment. Conventionally, a good

14 recirculating aquaculture system should incorporate unit processes to remove

15 suspended solids and organic matters, add oxygen, and control ammonia, nitrite, $\mathrm{pH}$

16 and pathogenic bacteria [2]. However, the present recirculating aquaculture systems,

17 which are mainly based on the biological method, suffer some problems, such as

18 frequent backwashing of the biofilter [3], complex biological denitrification process

19 [4], changeable biological nitrification beds [5], long hydraulic retention time or large

20 area occupied, and the long start-up period (3 or 4 weeks) [6].

21 Alternatively, membrane filtration is effective at removing particles and organic 
1 matters from wastewater in aquaculture process $[7,8]$. However, the fouling of

2 membranes caused by inorganic or organic matters retained on the membrane surface

3 is inevitable during the operation and decreases the membrane filtration capacity

$4 \quad[9,10]$. The general approaches to solve the membrane fouling problem are chemical

5 cleaning and back washing. Nevertheless, the periodical chemical cleaning or

6 backwashing of the membranes can generate additional wastewater and increase

7 economic costs. In recent years, the integration of advanced oxidation processes

8 (AOP) in the membrane filtration process to repress membrane fouling has become a

9 popular topic. Ozonation, one kind of AOP, is frequently used in aquaculture systems

10 for water quality improvements and disinfection [11,12]. The combination of

11 ozonation with the membrane filtration process is an effective approach to mitigating

12 membrane fouling in treating surface water [13-15]. In this process, the contaminants

13 (suspended and colloidal inorganic or organic substances) are intercepted and

14 deposited on the membrane surface by membrane separation, then the enriched

15 contaminants are degraded by ozonation. In the meantime, the membrane fouling can

16 be reduced to some extent and the water quality can be improved. Catalytic ozonation

17 by catalysts can promote the decomposition of ozone and the formation of hydroxyl

18 radicals $(\cdot \mathrm{OH})$ or other radicals $[16,17] \cdot \mathrm{OH}$ can react with almost all types of

19 contaminants due to their high reactivity. Consequently, coating ozone catalysts on the

20 membrane is a more promising subject for improving water quality and alleviating

21 membrane fouling [18-20]. 
1 Combined catalytic ozonation and membrane filtration was applied for surface

2 water $[13,14]$ or tertiary effluent $[15]$ treatment. However, no special attention was

3 paid to the removal of TAN and nitrite nitrogen $\left(\mathrm{NO}_{2}^{-}-\mathrm{N}\right)$ in this process. TAN and

$4 \quad \mathrm{NO}_{2}^{-}-\mathrm{N}$ are toxic to fish even at a low concentration. Long-term exposure of TAN or

$5 \quad \mathrm{NO}_{2}^{-}-\mathrm{N}$ would significantly inhibit the growth of fish because of a decrease in food

6 intake. Although TAN, $\mathrm{NO}_{2}^{-}-\mathrm{N}$ and dissolved organic matters are difficult to be

7 removed by membrane filtration alone, they are expected to be removed by catalytic

8 ozonation. There has been no reports about combination of catalytic ozonation with

9 membrane separation for aquaculture wastewater treatment till now. In the present

10 study, a pilot-scale coupling catalytic ozonation-ceramic membrane filtration system

11 was established for recirculating aquaculture wastewater treatment at a fish farm. This

12 study focused on the feasibility of the coupling system, the permeate flux of catalytic

13 membranes, the recovery ratio of the aquaculture wastewater and the water quality

14 which should meet the water quality requirement for aquaculture. The performances

15 of $\mathrm{Ti}-\mathrm{Mn} / \mathrm{TiO}_{2} / \mathrm{Al}_{2} \mathrm{O}_{3}$ and $\mathrm{TiO}_{2} / \mathrm{Al}_{2} \mathrm{O}_{3}$ catalytic membranes in terms of antifouling and

16 removal of total ammonia nitrogen and chemical oxygen demand (permanganate

17 index, CODMn) was also investigated.

18

\section{2. Experiential section}

\section{$20 \quad$ 2.1. Membrane preparation}

21 2.1.1. Preparation of intermediate layer $\left(\mathrm{TiO}_{2} / \mathrm{Al}_{2} \mathrm{O}_{3}\right.$ membranes $)$ 
1 Commercial tubular ceramic membranes $\left(\alpha-\mathrm{Al}_{2} \mathrm{O}_{3}, 30 \mathrm{~mm}(\mathrm{D}) \times 1016 \mathrm{~mm}(\mathrm{~L})\right.$

$2 \times 19$ channels, Jiexi Lishun technology, Inc., China) were first coated with rutile $\mathrm{TiO}_{2}$

3 (with a particle size of approximately $200 \mathrm{~nm}$ ) (JinZhou PengDa Titanium Dioxide

4 Manufacturing Co., Ltd., China) by a dip-coating method to form the $\mathrm{TiO}_{2}$

5 intermediate layer. A home-made dip-coating system was used to coat the membranes.

6 In the coating procedure, a cylindrical vessel was first filled with $\mathrm{TiO}_{2}$ suspension (8

7 wt.\%), and then the tubular ceramic membranes were immersed in the suspension for

82 min. Afterwards, the $\mathrm{TiO}_{2}$ suspension was discharged by a peristaltic pump at a

9 velocity of $200 \mu \mathrm{m} / \mathrm{s}$. This process was repeated twice. Subsequently, the coated

10 membranes were dried at $80{ }^{\circ} \mathrm{C}$ for $12 \mathrm{~h}$ and sintered at $1000{ }^{\circ} \mathrm{C}$ for $1 \mathrm{~h}$ in air with a

11 heating and cooling ramp of $10{ }^{\circ} \mathrm{C} / \mathrm{min}$.

12 2.1.2. Preparation of Ti-Mn oxide layer ( $\mathrm{Ti}-\mathrm{Mn} / \mathrm{TiO}_{2} / \mathrm{Al}_{2} \mathrm{O}_{3}$ membranes)

13 The Ti-Mn oxide layer was prepared as follows: Ti-Mn sol was prepared as

14 introduced in our previous work [21]. Pluronic F127 (45 g) was dissolved in $1000 \mathrm{~mL}$

15 ethanol, and then $250 \mathrm{~mL}$ titanium (IV) isopropoxide, $71.5 \mathrm{~mL}$ acetic acid, $38.45 \mathrm{~mL}$

16 manganese (II) nitrate solution (50\%), and $75 \mathrm{~mL}$ pure water were added to the

17 solution dropwise under vigorous stirring to obtain a light yellow transparent Ti-Mn

18 sol with a Ti/Mn molar ratio of $1: 0.1$. The $\mathrm{TiO}_{2} / \mathrm{Al}_{2} \mathrm{O}_{3}$ membrane channels were filled

19 with Ti-Mn sol for $2 \mathrm{~min}$, and then the Ti-Mn sol was extracted at a velocity of 200

$20 \mu \mathrm{m} / \mathrm{s}$. This dip-coating process was also repeated twice. After coating, the

$21 \mathrm{Ti}-\mathrm{Mn} / \mathrm{TiO}_{2} / \mathrm{Al}_{2} \mathrm{O}_{3}$ membranes were sintered in air at $550{ }^{\circ} \mathrm{C}$ for $1 \mathrm{~h}$ to fuse the Ti-Mn 
1 catalyst to the underlying $\mathrm{TiO}_{2} / \mathrm{Al}_{2} \mathrm{O}_{3}$ ceramic membranes.

\section{$2 \quad 2.2$ Membrane module}

3 The characteristics of the membrane module are listed in Table 1. Every tubular

4 ceramic membrane had a filtration area of $0.1 \mathrm{~m}^{2}$, and seven membranes were

5 assembled into one module (Fig. 1). Two modules were connected in parallel to obtain

6 the desired treatment capacity.

7

Table 1 Characteristics of membrane module

\begin{tabular}{|c|c|}
\hline \multicolumn{2}{|l|}{ Parameters } \\
\hline Type & Tubular \\
\hline Pore size & $2 \mu \mathrm{m}$ \\
\hline Material & Ceramic \\
\hline Porosity & $40 \%$ \\
\hline Effective filtration area per module & $0.7 \mathrm{~m}^{2}$ \\
\hline \multirow[t]{2}{*}{ Initial seawater flux $\left(20^{\circ} \mathrm{C}\right.$ ) } & $\mathrm{Ti}-\mathrm{Mn} / \mathrm{TiO}_{2} / \mathrm{Al}_{2} \mathrm{O}_{3}$ membrane: $269.6 \pm 4.6\left(\mathrm{~L} / \mathrm{m}^{2} \mathrm{~h}\right.$ bar $)$ \\
\hline & $\mathrm{TiO}_{2} / \mathrm{Al}_{2} \mathrm{O}_{3}$ membrane: $340.5 \pm 5.7\left(\mathrm{~L} / \mathrm{m}^{2} \mathrm{~h}\right.$ bar $)$ \\
\hline Membrane dimension & $30 \mathrm{~mm}(\mathrm{D}) \times 1016 \mathrm{~mm}(\mathrm{~L}) \times 19$ channels \\
\hline
\end{tabular}

8

9 A schematic diagram and photographs of the membrane module are shown in Fig. 1.

10 A cross-flow filtration mode at a flow velocity of $\sim 1.04 \mathrm{~m} / \mathrm{s}$ was adopted in all

11 membrane tests. 


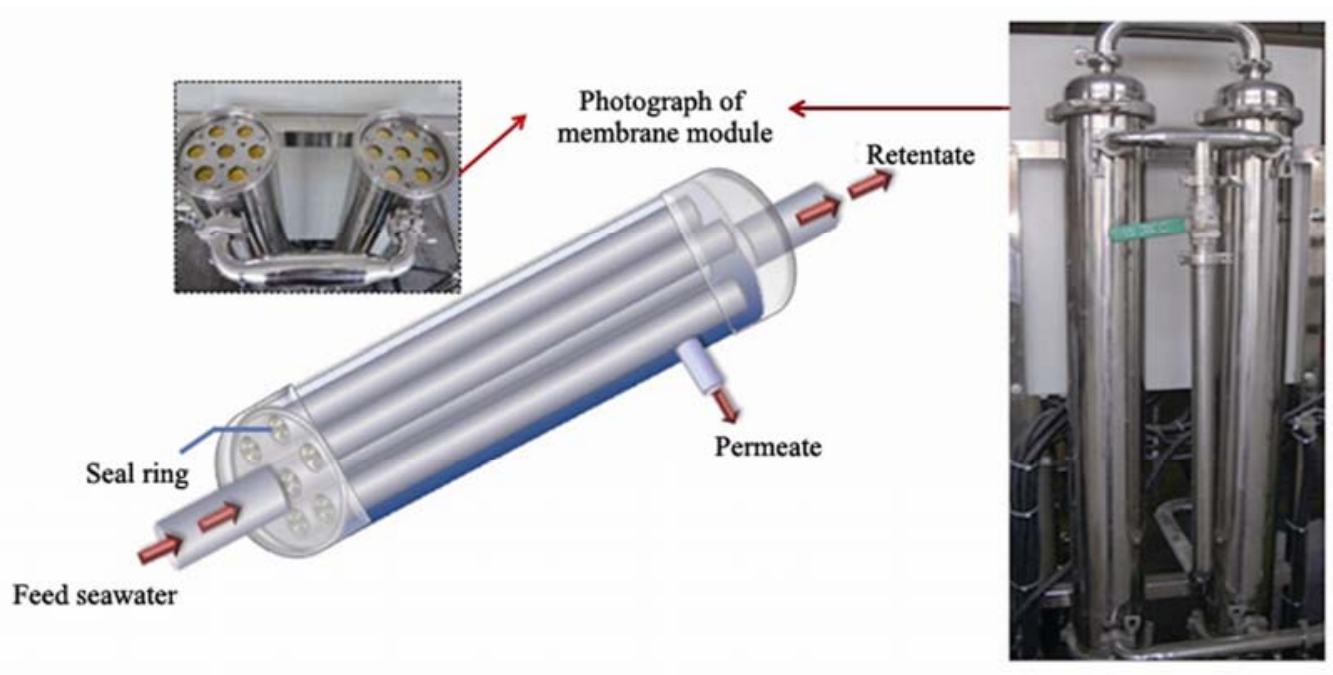

1 ozone was injected. Finally, the water flowed through an activated carbon filter for removing residual ozone, and then was recycled in this system. In this system, a

Fig. 1. A schematic diagram and photographs of the membrane module

\subsection{Pilot-scale system}

Fig. 2a shows the process flow diagram of the pilot-scale coupling ozonation-membrane filtration system. The coupling system was operated in a recycling mode as follows: The permeation was recycled to the culture pond with a booster pump. The retentate was recirculated in the loop using a gas-liquid mixing pump, and was discharged every $4 \mathrm{~h}$. In the coupling system, the fish (Paralichthys lethostigma) was cultured in a pond with $7 \mathrm{~m}^{3}$ of water. The water was discharged from a bottom-centered drain of the pond, then passed through a sand filter and got into a buffer tank. After that, the water flowed into the membrane module where gas-liquid mixing pump was used for mixing ozone and seawater adequately, and a 
1 backwash pump was used for back flushing. In addition, the backwash water was

2 stored in a storage tank. The membrane operating pressures were adjusted by the

3 concentrate control valve. The flow rate of the ozone gas was controlled by a flow

4 controller. The dissolved ozone concentration in the permeation was continuously

5 monitored by the iodometry method (GB/T 5750.11-2006, China). Temperature, water

6 yield, cross flow rate and pressure were monitored continuously using a

7 multifunctional sensor and were recorded using a data acquisition system. Fig. $2 b$

8 shows the major parts of the pilot-scale coupling ozonation-membrane filtration

9 system, including the membrane modules, pumps, an ozone generator (NP010-S-2,

10 Shandong NIPPON Photoelectricity Equipment co., Ltd, China), a data acquisition

11 system and a buffer tank. The operating conditions for the coupling

12 ozonation-membrane filtration system are summarized in Table 2.

13

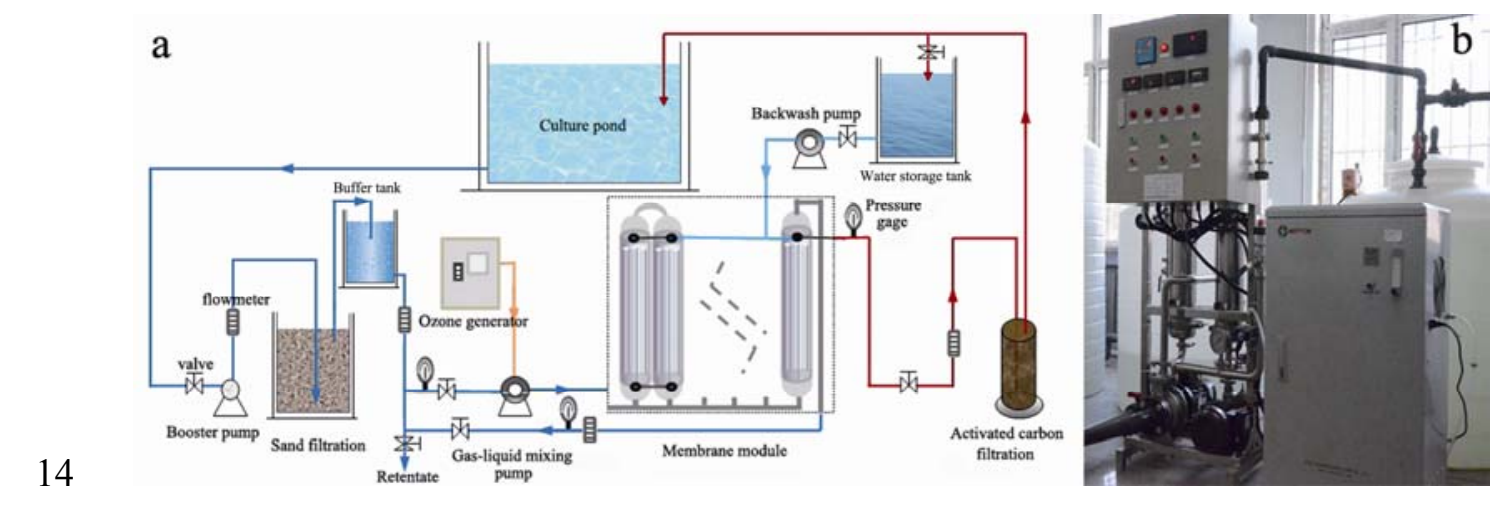

Fig. 2. Process flow diagram (a) and photograph (b) of the coupling ozonation-membrane

filtration system

17

Table 2 Operating conditions for the coupling ozonation-membrane filtration system 


\begin{tabular}{lll}
\hline Membrane filtration & Transmembrane pressure (TMP) & $2.22-2.30 \mathrm{bar}$ \\
& Cross flow velocity & $1.04 \pm 0.04 \mathrm{~m} / \mathrm{s}$ \\
Ozonation & Applied ozone dosage & $52\left(\mathrm{mg} \mathrm{O}_{3} / \mathrm{min}\right)$ \\
& Gas flow rate & $0.6 \mathrm{~L} / \mathrm{min}$ \\
Coupling system & Seawater recirculation rate & $4000 \mathrm{~L} / \mathrm{h}$ \\
& Temperature & $17-19^{\circ} \mathrm{C}$ \\
\hline
\end{tabular}

2 2.4. Aquaculture wastewater

3 The aquaculture wastewater was from an aquaculture farm in Dalian, China near

4 Bohai Bay producing Paralichthys lethostigma with a load of $12-15 \mathrm{~kg} / \mathrm{m}^{2}$. The

5 aquaculture wastewater was initially filtered with a sand filter prior to the treatment.

6 The water quality of the seawater after sand filtration is presented in Table 3. These

7 fish are very sensitive to total ammonia nitrogen (the lower the better) which should

8 normally be below $0.1 \mathrm{mg} / \mathrm{L}$. Nitrite nitrogen is also a key parameter and should

9 normally be controlled below $0.01 \mathrm{mg} / \mathrm{L}$.

10

11 Table 3 Aquaculture wastewater quality parameters (after sand filtration)

\begin{tabular}{ll}
\hline Parameters & values \\
\hline $\mathrm{COD}_{\mathrm{Mn}}(\mathrm{mg} / \mathrm{L})$ & $2.1-4.1$ \\
$\mathrm{UV}_{254}\left(\mathrm{~cm}^{-1}\right)$ & $0.073-0.095$ \\
Turbidity $(\mathrm{NTU})$ & $1.2-1.6$ \\
Total ammonia nitrogen $(\mathrm{mg} / \mathrm{L})$ & $0.2-0.4$ \\
Nitrite nitrogen $(\mathrm{mg} / \mathrm{L})$ & $0.03-0.04$ \\
\hline
\end{tabular}




\begin{tabular}{lc}
\hline Dissolved Oxygen $(\mathrm{mg} / \mathrm{L})$ & $6.5-8.2$ \\
Average particle size distribution $(\mathrm{nm})$ & $\sim 900$ \\
$\mathrm{pH}$ & $7.7-8.1$ \\
\hline
\end{tabular}

1

\section{2.5. Analytical methods}

3 The morphology of the surface and cross section of the membranes was observed

4 using a scanning electron microscope (SEM, S4800, Hitachi, Japan) equipped with an

5 energy dispersive X-ray spectroscopy (EDX). The total ammonia nitrogen

6 concentration was determined by Nessler's reagent colorimetric method (Water

7 quality standard for fisheries GB11607-89, China) and the nitrite nitrogen $\left(\mathrm{NO}_{2}^{-}-\mathrm{N}\right)$

8 concentration was determined by the ultraviolet spectrophotometry method (GB/T

9 5750.5-2006, China) using a UV-visible spectrophotometer (JASCO V-550, Japan).

$10 \mathrm{COD}_{\mathrm{Mn}}$ measurement was performed according to GB 17378.4-2007 (China) using

$11 \mathrm{KMnO}_{4}$ as oxidants. The average particle size of the fine solids in the permeation was

12 tested using a nano laser granulometer (Zetasizer ZS90, Malvern Instruments Ltd.,

13 Britain). Turbidity was detected using a turbidity meter (WGZ-200, Shanghai Xirui

14 instrument meter co., Ltd., China), and $\mathrm{pH}$ was detected using a digital $\mathrm{pH}$ meter

15 (PB-20, Sartorius, Germany).

16

17 3. Results and discussion

18 3.1. Characterization of membranes 
1 The $\mathrm{Al}_{2} \mathrm{O}_{3}$ tubular membrane and the $\mathrm{Al}_{2} \mathrm{O}_{3}$ membranes coated with $\mathrm{TiO}_{2}$ or

$2 \mathrm{Ti}-\mathrm{Mn} / \mathrm{TiO}_{2}$ are displayed in Fig. 3a. The SEM images of these three membrane

3 samples (Fig. 3b, c, d) showed that the $\mathrm{TiO}_{2}$ particles on the $\mathrm{TiO}_{2} / \mathrm{Al}_{2} \mathrm{O}_{3}$ membrane

4 were 100-300 nm (Fig. 3c). After being coated with Ti-Mn sol, the particles on the

5 membrane surface (Fig. 3d) became denser and the membrane surface seemed more

6 coarsened. The cross section of the Ti-Mn/TiO$/ \mathrm{Al}_{2} \mathrm{O}_{3}$ membrane (Fig. 3e) showed

7 that the coating thickness varied from $4.5 \mu \mathrm{m}$ to $6 \mu \mathrm{m}$.

8

9

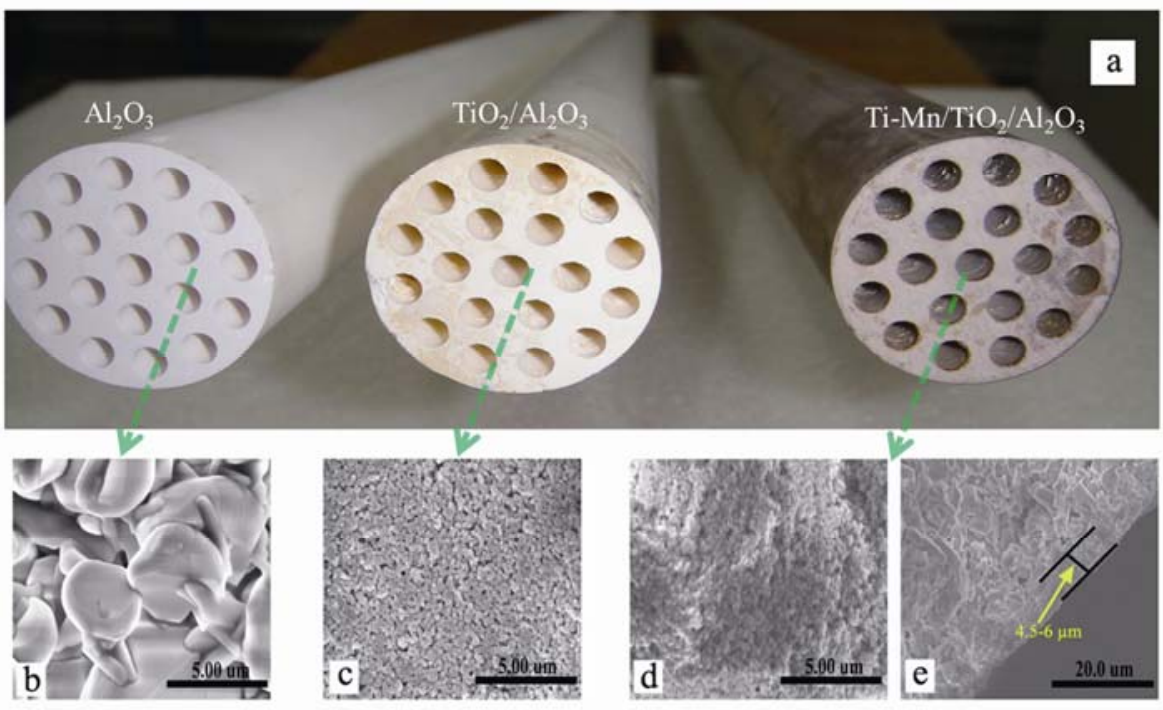

Fig. 3. (a) photograph of tubular ceramic membranes with different catalysts; SEM images of surface of $\mathrm{Al}_{2} \mathrm{O}_{3}$ membrane (substrate) (b), surface of $\mathrm{Al}_{2} \mathrm{O}_{3} / \mathrm{TiO}_{2}$ membrane (c), surface of $\mathrm{Ti}-\mathrm{Mn} / \mathrm{TiO}_{2} / \mathrm{Al}_{2} \mathrm{O}_{3}$ membrane (d), cross section of Ti-Mn/TiO $2 / \mathrm{Al}_{2} \mathrm{O}_{3}$ membrane (e)

4 The EDX images of the Ti-Mn/TiO $/ \mathrm{Al}_{2} \mathrm{O}_{3}$ membranes (Fig. 4a) showed that the

$5 \mathrm{Mn}$ and Ti were distributed uniformly on the membrane surface. The low Al content 
1 (3.763wt.\%) and high Ti contents (92.92\%) suggested that the membrane surface was

2 almost completely covered by the catalysts. The EDX analysis on its cross section

3 (Fig. 4b) also indicated that the porous Al-based substrate was coated by a

4 mesoporous $\mathrm{Ti}-\mathrm{Mn}$ layer, and some of the $\mathrm{Ti}$ and $\mathrm{Mn}$ even penetrated into the

5 membranes. The well-distributed catalyst indicated it likely played an important role

6 in the ozonation-membrane process.

7

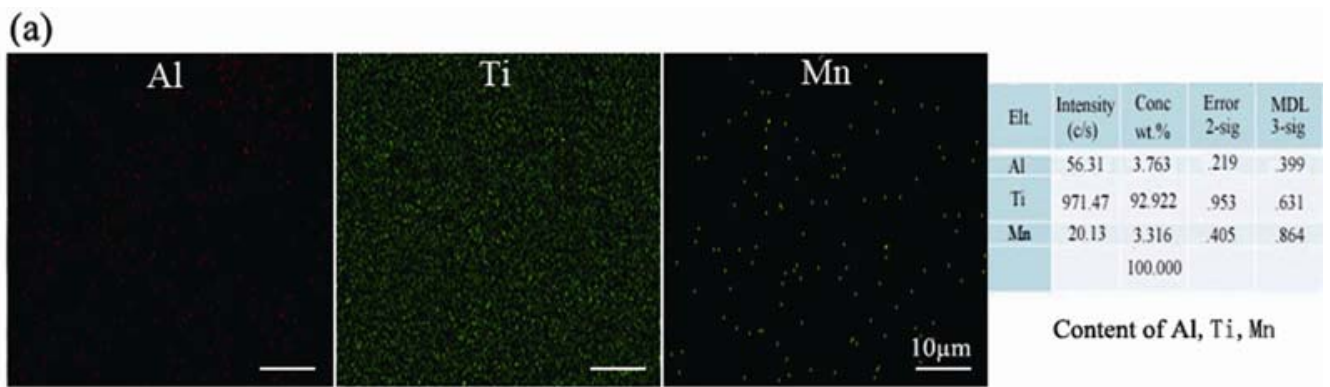

(b)

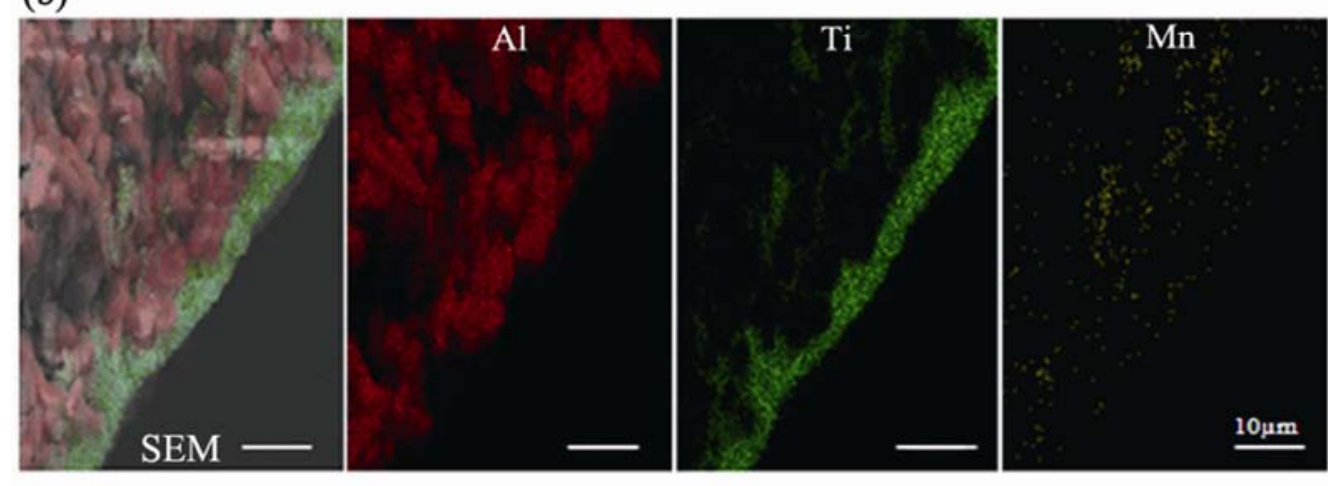

9 Fig. 4. EDX images of (a) surface of Ti-Mn/ $/ \mathrm{TiO}_{2} / \mathrm{Al}_{2} \mathrm{O}_{3}$ membrane and the content of three

10 elements, and (b) cross section of Ti-Mn/ $\mathrm{TiO}_{2} / \mathrm{Al}_{2} \mathrm{O}_{3}$ membrane.

11

\section{3.2. The effects of catalysts on the permeate flux}


1 The performance of the membranes with different catalysts in the aquaculture

2 seawater treatment was investigated. The flux data were unified to a standard

3 temperature of $20{ }^{\circ} \mathrm{C}$ using the following formula for eliminating the interference of

4 the water viscosity varying with temperature [22].

$$
J\left(20^{\circ} \mathrm{C}\right)=\left[Q_{p} \times 1.024^{(20-T)}\right] / \mathrm{S}
$$

6 Where $J=$ filtrate flux $\left(\mathrm{L} /\left(\mathrm{h} \mathrm{m}^{2}\right)\right), Q_{p}=$ measured filtrate flow $(\mathrm{L} / \mathrm{h})$ at temperature $T$

$7 \quad\left({ }^{\circ} \mathrm{C}\right), \mathrm{S}=$ membrane surface area $\left(\mathrm{m}^{2}\right)$.

8 Permeate flux is a very important parameter in membrane filtration. The pollutants

9 intercepted by membranes cause the membrane fouling and the degree of membrane

10 fouling could be characterized by the flux decline. The effects of the catalysts on the

11 normalized permeate flux are shown in Fig. 5. It is obvious that the Ti-Mn catalyst

12 coating improved the anti-fouling capacity of the membrane. In the presence of ozone,

13 the $\mathrm{Ti}-\mathrm{Mn} / \mathrm{TiO}_{2} / \mathrm{Al}_{2} \mathrm{O}_{3}$ membranes present a much higher permeate flux, with the

14 normalized permeate flux remaining stable at 0.56 until the test end at $4 \mathrm{~h}$, whereas

15 the permeate flux of the system with the $\mathrm{TiO}_{2} / \mathrm{Al}_{2} \mathrm{O}_{3}$ membranes kept decreasing. This

16 indicates that the Ti-Mn catalyst at the membrane surface had a stronger catalytic

17 ozonation capacity than $\mathrm{TiO}_{2}$, resulting in a better antifouling performance. The

18 antifouling performance of Ti-Mn membranes with ozone is due to the excellent

19 catalytic ozonation of Ti-Mn for effective degradation of the pollutants. As reported

20 by Ma et al., surface hydroxyl groups is considered to be the initiation for catalytic

21 ozonation or catalytic ozone decomposition to generate $\mathrm{OH}$ [23]. The point of zero 
1 charge of $\mathrm{Mn}$ oxide is relatively low $(\mathrm{pHzPC}=2.8-4.5)$, and at the $\mathrm{pH}$ of the

2 aquaculture water, the $\mathrm{H}_{2} \mathrm{O}$ molecules will be strongly adsorbed on the surface of $\mathrm{Mn}$

3 oxides, and dissociates in to $\mathrm{OH}^{-}$and $\mathrm{H}^{+}$, forming surface hydroxyl groups which are

4 active sites for catalytic ozonation [24]. The ozone is catalytically transformed

5 into $\mathrm{OH}$ and other active species, resulting in its high activity for degradation of

6 pollutants.

7

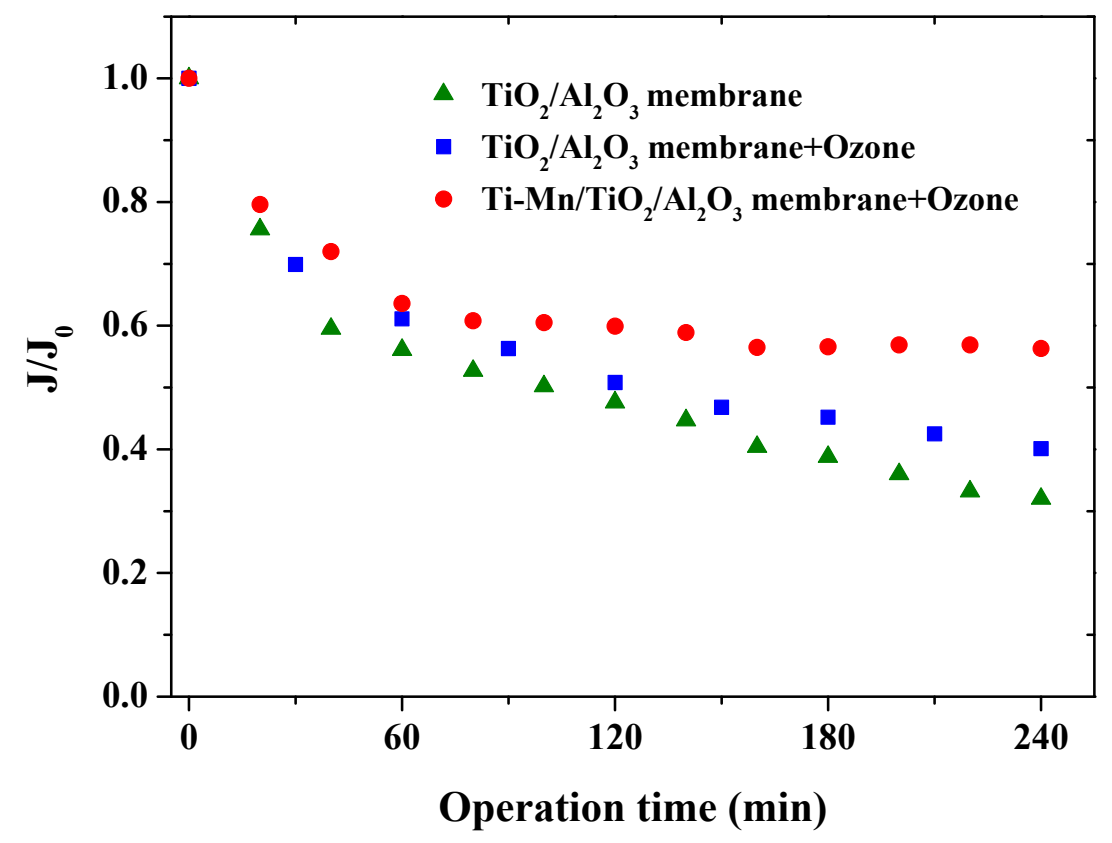

Fig. 5. Effects of the catalysts on normalized permeate flux $\left(\mathrm{J} / \mathrm{J}_{0}\right)$

10 (Conditions: TMP $=2.22-2.30$ bar, Ozone dose $=52 \mathrm{mgO}_{3} / \mathrm{min}, \mathrm{J}_{0}=$ initial seawater flux).

11

12 Because of the accumulation of pollutants at the membrane surface, the permeate

13 flux dropt rapidly for the membrane filtration alone. When the ozone was applied, 
1 some of the pollutants at the membrane surface could be decomposed, alleviating the

2 membrane fouling.

\section{$3 \quad$ 3.3. Suspended solids removal}

4 Suspended solids can increase turbidity and worsen the water quality, so they

5 should be removed from the water before reuse in aquaculture. In this study, the

6 turbidity and the average particle size of solids in the permeation were determined to

7 assess the removal of suspended solids. As shown in Fig. 6a, during the first half hour,

8 the removal of turbidity rose rapidly in each test because the foulants on the

9 membrane surface lowered the porosity and pore size of the membrane, causing it to

10 retain more suspended substances. These retained matters could function as filter

11 layers to intercept the suspended solids. The turbidity removal efficiency for the

$12 \mathrm{TiO}_{2} / \mathrm{Al}_{2} \mathrm{O}_{3}$ membranes without ozone was only $55 \%$, while it was up to $100 \%$ for

13 both the $\mathrm{TiO}_{2} / \mathrm{Al}_{2} \mathrm{O}_{3}$ and $\mathrm{Ti}-\mathrm{Mn} / \mathrm{TiO}_{2} / \mathrm{Al}_{2} \mathrm{O}_{3}$ membranes with ozone.

14 The membranes coated with Ti-Mn oxide showed the stronger ability to decompose

15 fine solids than the membranes coated with $\mathrm{TiO}_{2}$. As shown in Fig. 6b, the average

16 particle size of the fine solids in the permeation was $\sim 20 \mathrm{~nm}$ for the

$17 \mathrm{Ti}-\mathrm{Mn} / \mathrm{TiO}_{2} / \mathrm{Al}_{2} \mathrm{O}_{3}$ membranes with ozone, which is smaller than that for the

$18 \mathrm{TiO}_{2} / \mathrm{Al}_{2} \mathrm{O}_{3}$ membranes $(\sim 100 \mathrm{~nm})$. This result can be explained by Nawrocki's work

19 [17], in which metal oxide promoted the decomposition of ozone and enhanced the

20 generation of hydroxyl radicals or other radicals. Ti-Mn oxide, as a mixed catalyst,

21 exhibited greater capacity to catalyze ozone for producing hydroxyl radicals or other 
1 radicals than $\mathrm{TiO}_{2}$ in the membrane surface. Hydroxyl radicals can decompose

2 various pollutants into small structures [25] as well as break larger solids into smaller

3 solids. Accordingly, the average particle size of the fine solids in the permeation was

$4 \sim 400 \mathrm{~nm}$ for $\mathrm{TiO}_{2} / \mathrm{Al}_{2} \mathrm{O}_{3}$ membranes without ozone, nearly four times that with

5 ozone.

6

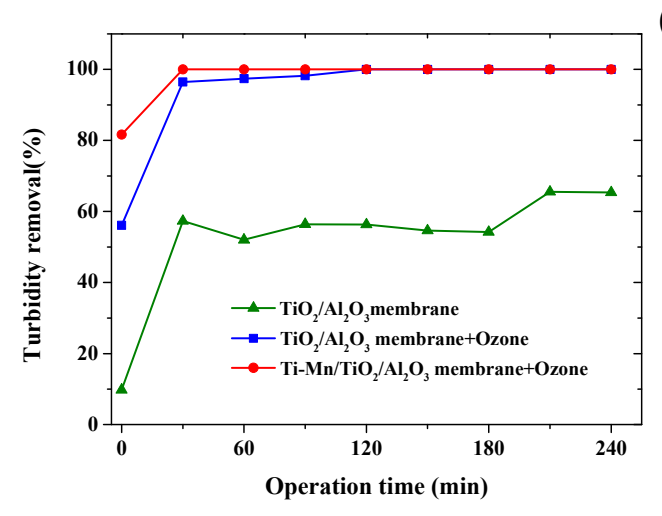

(a)

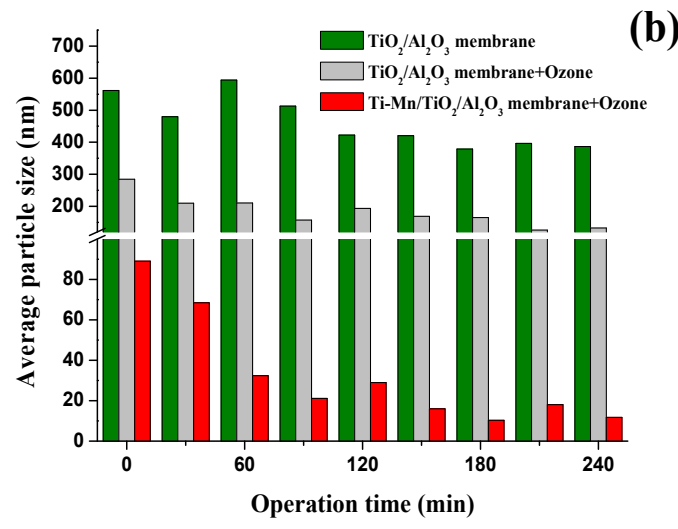

7 Fig. 6. Turbidity removal (a) and the average particle size of fine solids in the permeation (b) with

different membranes

9

\subsection{TAN and $\mathrm{NO}_{2}^{-}-\mathrm{N}$ removal}

11 It has been reported that TAN can be removed from seawater by ozonation [26] according to the following reactions [27]

$$
\mathrm{NH}_{3}+3 \mathrm{O}_{3} \rightarrow \mathrm{H}^{+}+\mathrm{NO}_{2}^{-}+\mathrm{H}_{2} \mathrm{O}+3 \mathrm{O}_{2}
$$

$$
\mathrm{NO}_{2}{ }^{-}+\mathrm{O}_{3} \rightarrow \mathrm{NO}_{3}{ }^{-}+\mathrm{O}_{2}
$$


1 fell to $0.1 \mathrm{mg} / \mathrm{L}$. The nitrite was easily removed and was nearly fully decomposed

2 when ozone was injected into the system. Two types of membranes

3 achieved the similar results, both meeting the water quality criterion for aquaculture

4 water reuse (GB 3097-1997, China). Compared with the nitrogen removal

5 performance using the two types of membranes, the predominance of the

$6 \mathrm{Ti}-\mathrm{Mn} / \mathrm{TiO}_{2} / \mathrm{Al}_{2} \mathrm{O}_{3}$ membranes was not significant. The most likely reason for this

7 result may be the conversion of ammonia into nitrogen in the presence of bromide

8 ions according to the following formula [28]

9

$$
\mathrm{Br}^{-}+\mathrm{O}_{3}+\mathrm{H}^{+} \rightarrow \mathrm{HBrO}+\mathrm{O}_{2}
$$

$$
2 \mathrm{NH}_{3}+3 \mathrm{HBrO} \rightarrow \mathrm{N}_{2}+3 \mathrm{Br}^{-}+3 \mathrm{H}_{2} \mathrm{O}+3 \mathrm{H}^{+}
$$

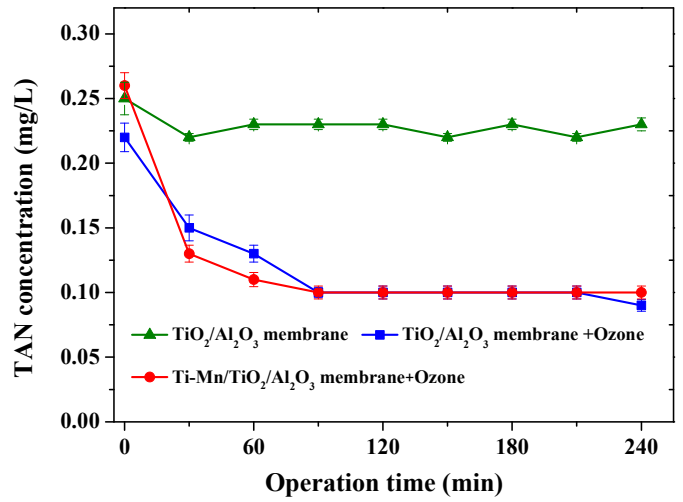

(a)

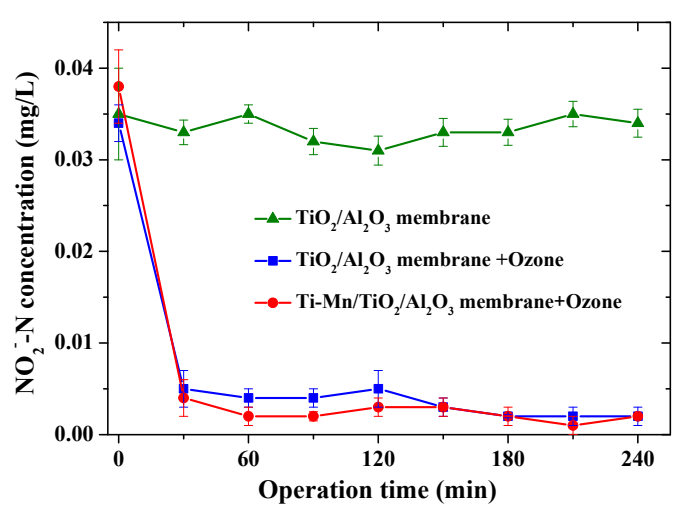

Fig. 7. TAN removal (a) and nitrite removal (b) with different membranes

14 In the membrane tests without ozone, the TAN and $\mathrm{NO}_{2}^{-}-\mathrm{N}$ concentration were

15 only slightly decreased, meaning the adsorption and interception of TAN and $\mathrm{NO}_{2}{ }^{-}-\mathrm{N}$ 
1 with the membrane itself was negligible.

\section{3.5. Effects of ozone dose on TAN and COD ${ }_{M n}$ removal}

3 The effect of ozone dose on the removal of TAN and CODMn was investigated in

4 this coupling ozonation-membrane filtration system. As can be seen in Fig. 8, the

5 concentration of TAN and $\mathrm{COD}_{\mathrm{Mn}}$ in the permeation began to decrease with

6 increasing ozone dose. This is because the higher ozone dose injected into the system

7 yield a higher dissolved ozone concentration in the seawater [14]. The higher

8 concentration of ozone dissolved in the seawater provided more opportunities to

9 produce free radicals and decompose the contaminants.

10

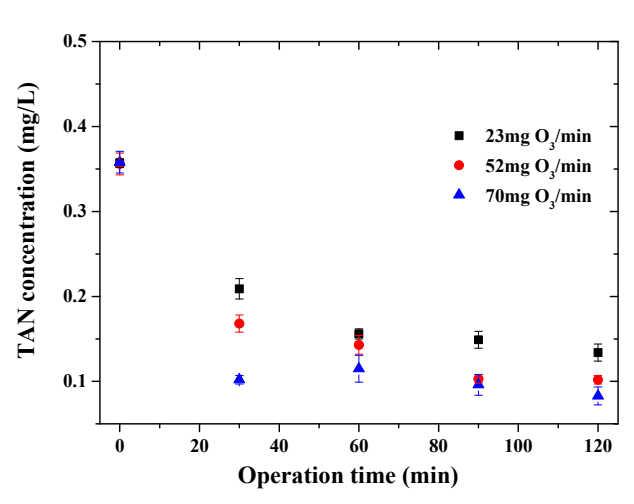

(a)

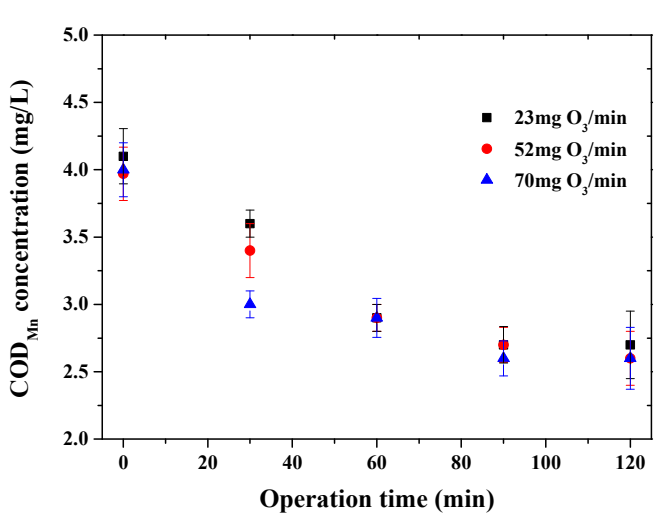

(b)

11 Fig. 8. Effects of ozone dose on (a) TAN concentration and (b) COD $_{\mathrm{Mn}}$ concentration in a coupling

12 ozonation-membrane filtration system (membranes coated with Ti-Mn/ $\mathrm{TiO}_{2}$ ) at a TMP of 2.2 bar

\section{3.6. COD $_{M n}$ and residual ozone removal}

15 In the aquaculture systems, the presence of organic matters will consume the 
1 dissolved oxygen. In this study, the concentration of CODMn in the permeation was

2 tested to evaluate the effects of catalyst coating on the removal of organic matters in

3 the aquaculture seawater. As shown in Fig. 9a, in the presence of ozone, the CODMn

4 removal of the Ti-Mn membranes was 52.1\%, much higher than that of $\mathrm{TiO}_{2}$ catalysis

5 membrane $(35.7 \%)$. This phenomenon indicates that more free $\cdot \mathrm{OH}$ or other active

6 species were generated by the catalytic ozonation of $\mathrm{Ti}-\mathrm{Mn}$ oxide than $\mathrm{TiO}_{2}$ alone,

7 causing better organics removal. The structure of the $\mathrm{Ti}-\mathrm{Mn} / \mathrm{TiO}_{2} / \mathrm{Al}_{2} \mathrm{O}_{3}$ membranes

8 may be another factor for higher $\mathrm{COD}_{\mathrm{Mn}}$ removal. The Ti-Mn oxides distributed over

9 both the membrane surface and the inner walls of the pores indicated that catalytic

10 ozonation not only occurs on the surface of the membranes but also in the inner pores

11 of the membranes. CODMn removal of membrane alone was only $15.4 \%$, meaning that

12 membrane alone for organic removal was not efficiently.

13 Considering that the residual ozone in the permeation is hazardous [29] to aquatic

14 organisms, an activated carbon filter was used to remove the residual ozone. The

15 concentration of $\mathrm{COD}_{\mathrm{Mn}}$ and dissolved ozone before and after the

16 activated carbon filter was detected. We also detected the CODMn concentration and

17 residual ozone after the permeation was only kept for an hour without any other

18 treatment to determine the effects of the activated carbon. From Fig. 9b we can see

19 that the ozone concentration only decreased from 0.76 to $0.54 \mathrm{mg} / \mathrm{L}$ when standing for

$2060 \mathrm{~min}$ after the membrane treatment. However, the residual ozone decreased to 0.012

$21 \mathrm{mg} / \mathrm{L}$ after the activated carbon filter, satisfying the aquaculture water requirements $(<$ 
$10.08 \mathrm{mg} / \mathrm{L})$. At the same time, the CODMn concentration decreased from $1.3 \mathrm{mg} / \mathrm{L}$ to

$20.9 \mathrm{mg} / \mathrm{L}$, possibly because the activated carbon served as a catalyst converting ozone

3 into hydroxyl radicals [30,31] which can be used for the further degradation of

4 organic matters. Taken together, the introduction of the activated carbon filter after the

5 coupling ozonation-membrane filtration system is necessary to control the potential

6 hazards of residual ozone.

7

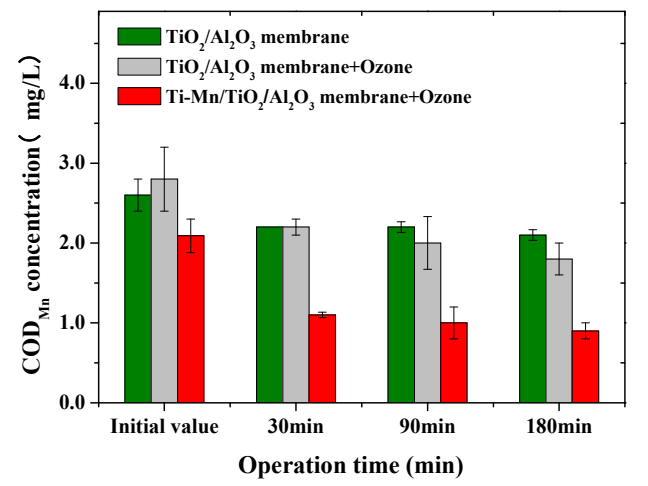

(a)

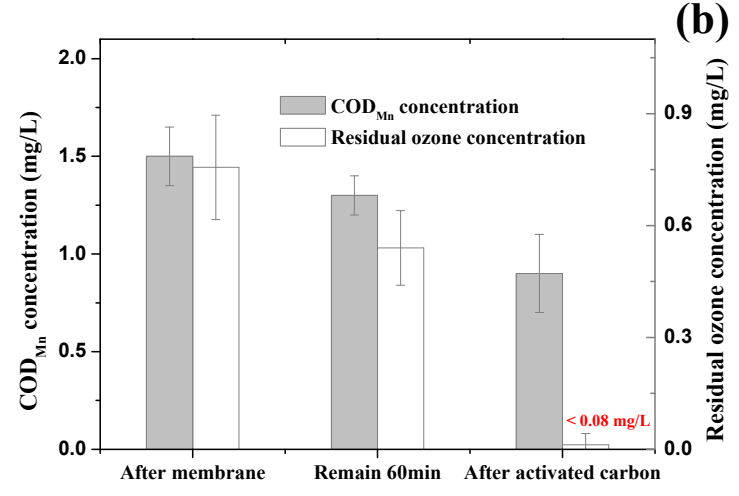

8 Fig. 9. (a) Effects of the catalysts on $\mathrm{COD}_{\mathrm{Mn}}$ removal and (b) removal of residual ozone and

9

$\mathrm{COD}_{\mathrm{Mn}}$ in the permeation

10

11 After $4 \mathrm{~h}$ of operation, approximately $2000 \mathrm{~L}$ permeation was produced with $88 \mathrm{~L}$

12 of retentate discharged with the recovery ratio being up to $95.8 \%$. For aquaculture

13 systems, the high recovery rate could decrease the consumption of fresh water.

14 This study demonstrated that coupling catalytic ozonation with membrane filtration

15 was an effective method for aquaculture wastewater treatment. Ti-Mn/ $/ \mathrm{TiO}_{2} / \mathrm{Al}_{2} \mathrm{O}_{3}$ 
1 membranes showed the better performance in permeate flux and organic removal than

$2 \mathrm{TiO}_{2} / \mathrm{Al}_{2} \mathrm{O}_{3}$ membranes. Membrane filtration alone was not feasible in the treatment

3 of aquaculture wastewater, showing a rapid drop of membrane flux, inefficient

4 removal of suspended solids and organic matters, and almost no degradation of TAN

5 and $\mathrm{NO}_{2}^{-}-\mathrm{N}$.

6

\section{4. Conclusions}

8 In this work, a pilot-scale coupling catalytic ozonation-ceramic microfiltration

9 membrane filtration system was set up successfully for a recirculating aquaculture

10 water treatment. This coupling system obtained satisfactory results, with the permeate

11 quality meeting the requirement of aquaculture water reuse, the short start-up period,

12 and the stable operation conditions. In addition, the $\mathrm{Ti}-\mathrm{Mn} / \mathrm{TiO}_{2} / \mathrm{Al}_{2} \mathrm{O}_{3}$ membranes in

13 the coupling system significantly reduced membrane fouling and organic matters. The

14 ozone dose was preferable for TAN and CODMn removal. Considering the residual

15 ozone is harmful to the aquatic organisms, an activated carbon filter is necessary after

16 the membrane filtration to remove the residual ozone. The results showed that this

17 coupling catalytic ozonation-ceramic membrane filtration system is expected to be a

18 promising strategy for recirculating aquaculture water treatment.

\section{Acknowledgments}


1 This work was supported by the National Basic Research Program of China (2011C

2 B936002), National Natural Science Foundation of China (NSFC-JST 21261140334),

3 Open Project of Key Lab. of Contaminated Environment Control and Regional

4 Ecology Safety (SYU-KF-L-01) and Key Lab. of Regional Environment

5 Eco-remediation (MOE, SYU-KF-E-01), the Natural Science Foundation of Liaoning

6 province of China (2014020149), and PCSIRT_13R05.

7

8 References

[1] M. Badiola, D. Mendiola, J. Bostock, Recirculating aquaculture systems (RAS) analysis: Main issues on management and future challenges, Aquacult. Eng. 51 (2012) 26-35.

[2] M.L. Thomas, P.M. Michael, R. James, Recirculating aquaculture tank production systems-An overview of critical considerations, SRAC Publication No. 451, 1998.

[3] L. Yang, L.S. Chou, W.K. Shieh, Biofilter treatment of aquaculture water for reuse applications, Water Res. 35 (2001) 3097-3108.

[4] G. Ruiz, D. Jeison, R. Chamy, Nitrification with high nitrite accumulation for the treatment of wastewater with high ammonia concentration, Water Res. 37 (2003) 1371-1377.

[5] D.W. Graham, C.W. Knapp, E.S.V. Vleck, K. Bloor, Experimental demonstration of chaotic instability in biological nitrification, The ISME Journal 1 (2007) 385-393.

[6] M.P. Masser, J. Rackocy, T.M. Losordo, Recirculating aquaculture tank production systems: Management of recirculating systems, Management of 
recirculating systems, SRAC Publication no. 452, 1999.

[7] R.C. Viadero, J.A. Noblet, Membrane filtration for removal of fine solids from aquaculture process water, Aquacult. Eng. 26 (2002) 151-169.

[8] B. Gemende, A. Gerbeth, N. Pausch, A.V. Bresinsky, Tests for the application of membrane technology in a new method for intensive aquaculture, Desalination 224 (2008) 57-63.

[9] S. Hong, M. Elimelech, Chemical and physical aspects of natural organic matter (NOM) fouling of nanofiltration membranes, J. Membr. Sci. 132 (1997) 159-181.

[10] K.J. Howe, M.M. Clark, Fouling of microfiltration and ultrafiltration membranes by natural waters, Environ. Sci. Technol. 36 (2002) 3571-3576.

[11] M.S. Tango, G.A. Gagnon, Impact of ozonation on water quality in marine recirculation systems, Aquacult. Eng. 29 (2003) 125-137.

[12] S.T. Summerfelt, Ozonation and UV irradiation-an introduction and examples of current applications, Aquacult. Eng. 28 (2003) 21-36.

[13] B. Schlichter, V. Mavrovb, H. Chmiel, Study of a hybrid process combining ozonation and microfiltration/ultrafiltration for drinking water production from surface water, Desalination 168 (2004) 307-317.

[14] S.H. You, D.H. Tseng, W.C. Hsu, Effect and mechanism of ultrafiltration membrane fouling removal by ozonation, Desalination 202 (2007) 224-230.

[15] J. Kim, S.H.R Davies, M.J. Baumann, Effect of ozone dosage and hydrodynamic conditions on the permeate flux in a hybrid ozonation-ceramic ultrafiltration system treating natural waters, J. Membr. Sci. 311 (2008) 165-172.

[16] B.K. Hordern, M. Ziółek, J. Nawrocki, Catalytic ozonation and methods of enhancing molecular ozone reactions in water treatment, Applied Catalysis B: Environmental. 46 (2003) 639-669.

[17] J. Nawrocki, B.K. Hordern, The efficiency and mechanisms of catalytic ozonation, Appl. Catal., B. 99 (2010) 27-42. 
[18] B.S. Karnik, S.H. Davies, M.J. Baumann, S.J. Masten, Fabrication of catalytic membranes for the treatment of drinking water using combined ozonation and ultrafiltration, Environ. Sci. Technol. 39 (2005) 7656-7661.

[19] B.S. Karnik, S.H.R. Davies, K.C. Chen, D.R. Jaglowski, M.J. Baumann, S.J. Masten, Effects of ozonation on the permeate flux of nanocrystalline ceramic membranes, Water Res. 39 (2005) 728-734.

[20] L.M. Corneal, M.J. Baumann, S.J. Masten, Mn oxide coated catalytic membranes for hybrid ozonation-membrane filtration: Membrane microstructural characterization, J. Membr. Sci. 369 (2011) 182-187.

[21] Y.Q. Zhu, S. Chen, X. Quan, Y.B. Zhang, C. Gao, Y.J. Feng, Hierarchical porous ceramic membrane with energetic ozonation capability for enhancing water treatment, J. Membr. Sci. 431 (2013) 197-204.

[22] S.G. Lehman, L. Liu, Application of ceramic membranes with pre-ozonation for treatment of secondary wastewater effluent, Water Res. 43 (2009) 2020-2028.

[23] J Ma, N.G.D Graham, Degradation of atrazine by manganese-catalysed ozonation: Influence of humic substances. Water Res. 33 (1999) 785-793.

[24] L Yang, C Hu, Y.L Nie, J.H Qu, Catalytic ozonation of selected pharmaceuticals over mesoporous alumina-supported manganese oxide, Environ. Sci. Technol. 43 (2009) 2525-2529

[25] C.P. Huang, C.D. Dong, Z.H. Tang, Advanced chemical oxidation: Its present role and potential future in hazardous waste treatment, Waste Manage. 13 (1993) 361.

[26] S.H. Lin, Y.L. Yen, Ammonia and nitrite removal from sea water by ozonation, Environ. Technol. 18 (1997) 65-73.

[27] M. Yang, K. Uesugia, Ammonia removal in bubble column by ozonation in the presence of bromide, Water Res. 33 (1999) 1911-1917.

[28] S. Khuntia, S.K. Majumder, Removal of ammonia from water by ozone 
microbubbles, Ind. Eng. Chem. Res. 52 (2013) 318-326.

[29] J.P. Schroeder, P.L. Croot, B. Von Dewitz, Potential and limitations of ozone for the removal of ammonia, nitrite, and yellow substances in marine recirculating aquaculture systems, Aquacult. Eng. 45 (2011) 35-41.

[30] U. Jans, J. Hoigne, Activated carbon and carbon black catalyzed transformation of aqueous ozone into OH-Radicals, OS\&E, 20 (1998) 67-90.

[31] M.S. Polo, U.V. Gunten, J.R. Utrill, Efficiency of activated carbon to transform ozone into $\mathrm{OH}$ radicals: Influence of operational parameters, Water Res. 39 (2005) 3189-3198. 